\title{
PENGEMBANGAN PEMBELAJARAN ILMU PENGETAHUAN SOSIAL SEKOLAH DASAR BERWAWASAN SOSIAL-BUDAYA
}

\author{
Abu Dharin, Donny Khoirul Aziz, Hendri Purbo Waseso \\ Institut Agama Islam Negeri Purwokerto
}

\begin{abstract}
This paper describes the development of social science (IPS) learning in socialcultural and PAIKEM-based elementary schools. Development of Elementary School Social Sciences Learning based on socio-cultural and PAIKEM-based learning as an innovative step in social studies learning at the elementary school level can minimize deficiencies in teaching students to understand social studies in elementary schools as well as to improve the quality of elementary school social studies learning processes. teachers need to be active, creative and selective in applying learning models and approaches. Based on the main problems and results and discussion as described above, several conclusions can be formulated as follows: 1) learning procedures with learning models with socio-cultural approach provide optimal flexibility for students to improvise during the course of learning so that they can create a climate and conducive learning activities; 2) The effectiveness of the socio-cultural learning model towards increasing understanding of social studies material by students, it appears that students' understanding of the material taught shows an increasing graph, and at the model testing stage, the results of evaluation tests conducted indicate that the average evaluation evaluation score students who are taught by learning models with socio-cultural approaches are higher than the average scores of students who are taught by conventional learning models; and 3) there is an increase in the socio-cultural literacy of students related to the material taught in social studies learning with a socio-cultural approach and based on PAIKEM.
\end{abstract}

Keywords: Elementary School Social Studies Learning, social-cultural insight, and PAIKEM

Abstrak: Dapat diformulasikan simpulan hasil penelitian sebagai berikut: (1) prosedur pembelajaran dengan model belajar berpendekatan sosial-budaya memberikan keleluasaan yang optimal bagi peserta didik untuk berimprovisasi selama berlangsungnya pembelajaran sehingga dapat menciptakan iklim dan aktivitas belajar yang kondusif; (2) Efektivitas model belajar berpendekatan sosial-budaya terhadap peningkatan pemahaman materi IPS oleh peserta didik, tampak bahwa pemahaman peserta didik terhadap materi yang diajarkan memperlihatkan grafik yang meningkat, dan pada tahap uji coba model, hasil tes evaluasi yang dilakukan menunjukkan bahwa rerata skor evaluasi belajar peserta didik yang dibelajarkan dengan model belajar berpendekatan sosial-budaya lebih tinggi daripada skor rerata peserta didik yang dibelajarkan dengan model belajar konvensional; dan (3) terjadi peningkatan literasi sosial-budaya peserta didik yang berkaitan dengan materi yang 
dibelajarkan dalam pembelajaran IPS berpendekatan sosial-budaya dan berbasis PAIKEM.

Kata Kunci: Pembelajaran IPS SD, berwawasan sosial budaya, dan PAIKEM

\section{A. PENDAHULUAN}

Ilmu pengetahuan sosial merupakan ilmu pengetahuan yang sangat esensial dan strategis dalam membentuk, mengembangkan, dan melatih peserta didik menjadi warga masyarakat, bangsa, dan negara yang mempunyai pengetahuan, pemahaman, dan keterampilan yang komprehensif sehingga mampu menjalani kehidupan masyarakat modern dan tataran kehidupan masyarakat global. Tujuan pembelajaran IPS tidak semata-mata untuk menyiapkan peserta didik melanjutkan pendidikan ke jenjang yang lebih tinggi, namun yang lebih penting adalah pembentukan dan pelatihan peserta didik untuk memiliki literasi sosial dan budaya kebangsaan yang tinggi. Untuk itu, pembelajaran IPS di sekolah seyogyanya mengacu pada format "keterpaduan dan kesejajaran" dengan isu-isu sosial aktual yang ada dan berkembang di masyarakat, seperti; abrasi moral kebangsaan, krisis kepercayaan, masalah hak asasi manusia, masalah keadilan, pencemaran lingkungan, dan abrasi nilai-nilai budaya kebangsaan.

Banyak guru yang mendasarkan diri pada asumsi yang salah dalam membelajarkan IPS. Mereka beranggapan bahwa IPS adalah pengetahuan yang dapat ditransfer sedemikian rupa secara utuh dari kepala guru ke kepala peserta didik dengan pola teks book oriented. Akibatnya, mungkin saja guru telah merasa mengajar dengan baik, namun realitasnya peserta didik tidak belajar secara optimal. Di samping itu, pola pembelajaran yang demikian menyebabkan pembelajaran IPS "gersang" dan tercabut dari akar budaya masyarakat yang merupakan sumber dari pembelajaran IPS itu sendiri. Persoalan ini semakin kompleks, mengingat materi IPS pada jenjang sekolah sangat luas dan abstrak. Padahal, secara psikologis, peserta didik khususnya pada jenjang sekolah dasar masih berada pada tahap operasional konkret.

Kondisi pembelajaran IPS dewasa ini khususnya pada jenjang sekolah dasar, menunjukkan indikasi bahwa pola pembelajaran yang dikembangkan oleh guru cenderung bersifat guru sentris sehingga peserta didik hanya menjadi objek pembelajaran. Model pembelajaran yang demikian, lebih cenderung berangkat dari asumsi dasar bahwa pembelajaran IPS hanya dimaksudkan untuk mentransfer pengetahuan (transfer of knowledge) atau konsep dari kepala guru ke kepala siswa. Akibatnya, mungkin guru telah merasa membelajarkan namun siswa belum belajar.

Sebagai salah satu komponen dalam kegiatan belajar mengajar (KBM), guru memiliki posisi yang menentukan keberhasilan pembelajaran, karena fungsi utama guru ialah merancang, mengelola, dan mengevaluasi pembelajaran (Gagne, 1974). Ausubel (1968) mengatakan bahwa guru bertugas mengalihkan seperangkat pengetahuan yang terorganisasikan sehingga pengetahuan itu menjadi bagian dari sistem pengetahuan siswa. 
Sejalan dengan itu pula, Kurikulum Berbasis Kompetensi (KBK) menegaskan bahwa kedudukan guru dalam kegiatan belajar mengajar sangat strategis dan menentukan. Strategis karena guru akan menentukan kedalaman dan keluasan materi pelajaran. Menentukan karena gurulah yang memilah dan memilih bahan pelajaran yang akan disajikan kepada peserta didik. Salah satu faktor yang mempengaruhi guru dalam upaya memperluas dan memperdalam materi ialah rancangan pembelajaran yang efektif, efisien, menarik, dan hasil pembelajaran yang bermutu tinggi dapat dilakukan dan dicapai oleh setiap guru.

Berdasarkan pengamatan, guru di lapangan jarang memanfaatkan fungsi ini secara optimal. Kondisi ini disebabkan oleh kenyataan bahwa tugas yang diemban guru sebagai perancang pembelajaran adalah sangat rumit, karena berhadapan dengan dua variabel di luar kontrolnya, yaitu cakupan isi pembelajaran yang telah ditetapkan terlebih dahulu berdasarkan tujuan yang akan dicapai, dan siswa yang membawa seperangkat sikap, kemampuan awal, dan karakteristik perseorangan lainnya ke dalam situasi pembelajaran.

Guru hanya berpeluang untuk memanipulasi strategi atau metode pembelajaran di bawah kendala karakteristik tujuan pembelajaran dan siswa. Hal ini diakui oleh Reigeluth (1983) yang menyatakan bahwa pada hakikatnya hanya variabel metode pembelajaran yang berpeluang besar untuk dapat dimanipulasi oleh setiap guru dan perancang pembelajaran.

Dalam melaksanakan kegiatan belajar-mengajar, pada umumnya guru menggunakan metode secara sembarangan. Penggunaan metode secara sembarangan ini tidak berdasarkan pada analisis kesesuaian antara tipe isi pelajaran dengan tipe kinerja (performansi) yang menjadi sasaran belajar. Padahal keefektifan suatu metode pembelajaran sangat ditentukan oleh kesesuaian antara tipe isi dengan tipe performansi. Gagne dan Briggs (1979) mengatakan bahwa suatu hasil belajar memerlukan kondisi belajar internal dan kondisi belajar eksternal yang berbeda. Sejalan dengan ini, Degeng (1989) menyatakan, suatu metode pembelajaran sering kali hanya cocok untuk belajar tipe isi tertentu di bawah kondisi tertentu. Hal ini berarti bahwa untuk belajar tipe isi yang lain di bawah kondisi yang lain, diperlukan metode pembelajaran yang berbeda.

Salah satu kendala yang dihadapi oleh guru untuk menghasilkan metode atau model pembelajaran Ilmu Pengetahuan Sosial (IPS) yang efektif ialah fakta bahwa guru berhadapan dengan materi IPS yang memiliki cakupan sangat kompleks. Hal ini dapat menyulitkan guru untuk menstrukturkan dan membuat sistem materi pelajaran secara cermat berdasarkan tipe isi dalam kaitannya dengan tujuan pembelajaran. Menstruktur dan mensistematisasikan pelajaran secara cermat sesuai dengan sasaran belajar bukanlah tugas yang mudah. Tugas ini memerlukan pengetahuan yang cukup baik tentang perancangan pembelajaran. Di sisi lain, ternyata kemampuan guru dalam merencanakan dan mengimplementasikan kurikulum belum memuaskan (Gufron, 1993). 
Pelaksanaan proses pembelajaran dari berbagai mata pelajaran di Sekolah Dasar pada umumnya bertujuan untuk mengembangkan seluruh potensi yang ada pada diri peserta didik, baik potensi dalam aspek kognitif, aspek afektif maupun aspek psikomotorik.

Ilmu Pengetahuan Sosial (IPS) merupakan salah satu mata pelajaran yang diberikan mulai dari Sekolah Dasar (SD) sampai Sekolah Menengah Pertama (SMP) berusaha memberikan wawasan secara komprehensif tentang peristiwa, fakta, konsep, dan generalisasi yang berkaitan dengan isu-isu sosial. Berbagai tradisi dalam ilmu sosial, termasuk konsep, teori, fakta, struktur, metode dan penanaman nilai-nilai dalam ilmu sosial perlu dikemas secara pedagogis, integratif, dan komunikatif serta relevan dengan situasi dan kondisi yang berkembang dalam masyarakat.

Dalam dokumen kurikulum, mata pelajaran IPS mengarahkan peserta didik untuk dapat menjadi warga negara Indonesia yang demokratis dan bertanggung jawab serta warga dunia yang cinta damai. Fenomena kehidupan global di masa mendatang yang penuh dengan tantangan, menuntut mata pelajaran IPS untuk dirancang bisa mengembangkan pengetahuan, pemahaman, dan kemampuan analisis terhadap kondisi sosial masyarakat dalam memasuki kehidupan bermasyarakat yang dinamis.

Pembelajaran IPS di Sekolah Dasar perlu disusun secara sistematis, komprehensif, dan terpadu dalam proses pembelajaran menuju kedewasaan dan keberhasilan dalam kehidupan bermasyarakat. Pendekatan tersebut diharapkan mampu membina siswa agar menjadi warga negara Indonesia yang bertanggung jawab dan warga dunia yang efektif, dalam masyarakat global yang selalu mengalami perubahan setiap saat. Untuk itu, pembelajaran IPS perlu dirancang untuk membangun dan merefleksikan kemampuan siswa dalam kehidupan bermasyarakat yang selalu berubah dan berkembang secara terus menerus.

Menurut KTSP (2006), Tujuan Mata Pelajaran Ilmu Pengetahuan Sosial di Sekolah Dasar agar peserta didik memiliki kemampuan sebagai berikut: 1) Mengenal konsepkonsep yang berkaitan dengan kehidupan masyarakat dan lingkungannya; 2) Memiliki kemampuan dasar untuk berpikir logis dan kritis, rasa ingin tahu, inkuiri, memecahkan masalah, dan keterampilan dalam kehidupan sosial; 3) Memiliki komitmen dan kesadaran terhadap nilai-nilai sosial kemanusiaan; 4) Memiliki kemampuan berkomunikasi, bekerjasama dan berkompetisi dalam masyarakat yang majemuk dan di tingkat lokal, nasional dan global.

Jarolimek (1993: 8) mengharapkan bahwa pendidikan pengetahuan sosial hendaknya mampu mengembangkan aspek pengetahuan dan pengertian (knowledge and understanding), aspek sikap dan nilai (attitude and value) serta aspek keterampilan (skill) pada diri siswa. Aspek pengetahuan dan pengertian berkaitan dengan pemberian bekal pengetahuan dan pemahaman siswa tentang dunia dan kehidupan masyarakat di sekitarnya, aspek sikap berkaitan dengan pemberian bekal mengenai dasar-dasar etika dan norma yang nantinya menjadi orientasi nilai dalam kehidupannya di masyarakat. Sedangkan aspek 
keterampilan meliputi keterampilan sosial (social skill) dan keterampilan intelektual (intellectual skill) agar siswa tanggap terhadap permasalahan sosial di sekitarnya dan mampu bekerja sama dengan orang lain dalam kehiduapn sehari-hari.

Sedangkan menurut Schuncke (1988: 8-9) sekolah merupakan wahana yang sangat penting dalam pendidikan nilai dan norma serta perilaku yang demokratis. Penanaman nilai dan norma serta perilaku demokratis secara normatif merupakan tanggung jawab seluruh guru di suatu sekolah. Namun secara legal-akademik tanggung jawab tersebut ada pada guru mata pelajaran Pendidikan Kewarganegaraan maupun Ilmu Pengetahuan Sosial. Oleh karena itu, kajian pengembangan nilai dan norma serta sosialisasi perilaku demokratis perlu dikembangkan secara kreatif dalam proses pembelajaran PKn dan IPS.

Untuk mencapai tujuan mata pelajaran IPS di Sekolah Dasar tersebut perlu dikembangkan strategi pembelajaran IPS yang aktif, kreatif, efektif, inovatif dan menyenangkan (PAIKEM). Guru perlu mengembangkan strategi pembelajaran yang berorientasi pada siswa (student centered) agar siswa terdorong untuk berpartisipasi aktif dalam proses pembelajaran. Untuk memotivasi siswa agar berpartisipasi secara aktif perlu dikembangkan strategi pembelajaran yang aktif, kreatif, efektif dan menyenangkan agar kualitas proses pembelajaran IPS lebih memadai.

Berdasarkan kajian terhadap masalah di atas, tulisan ini difokuskan pada pengembangan pembelajaran IPS Sekolah Dasar berwawasan sosial-budaya dan berbasis PAIKEM. Pemilihan pembelajaran IPS Sekolah Dasar berwawasan sosial-budaya dan berbasis PAIKEM adalah sebagai salah satu alternatif dalam memperbaiki kualitas proses dan produk pembelajaran IPS di sekolah dasar didasari oleh rasional bahwa: (1) model belajar berpendekatan sosial-budaya menawarkan sejumlah kemudahan dan peluang kepada guru dalam meningkatkan motivasi dan keterlibatan belajar peserta didik, sehingga model ini layak untuk dikembangkan untuk memperbaiki kualitas proses dan produk pembelajaran IPS, (2) adanya rangkaian kegiatan belajar dan tindakan langsung (action) dalam tahapan model belajar berpendekatan sosial-budaya, dapat mengondisikan peserta didik untuk belajar secara optimal sambil melatih secara langsung kemampuan dan keterampilan yang telah dipelajarinya di kelas, dan (3) model belajar berpendekatan sosial-budaya memiliki nilai lebih dalam kaitannya dengan pengembangan dan peningkatan pemahaman materi dan pelatihan keterampilan sosial peserta didik dalam latar sosial yang nyata, yang selama ini aspek tersebut cenderung terabaikan dalam pembelajaran IPS.

\section{B. METODE}

Kajian ini dilakukan dengan menganalisa sumber-sumber berbasis teks berupa buku, jurnal dan dipadukan dengan pengalaman empiris penulis. Oleh karena jenis penelitian yang digunakan adalah library research, maka pengumpulan data dilakukan dengan dokumentasi. Adapun analisis datanya menggunakan content analysis dengan cara

mereduksi sumber data yang telah dikumpulkan kemudian membuat klasifikasi dan 
menarik kesimpulan analisis yang telah dilakukan. Adapun fokus kajiannya adalah pada pengembangan model-model pembelajaran, pendekatan pembelajaran, metode pembelajaran dan media pembelajaran IPS Sekolah Dasar. Kajian tersebut dideskripsikan dengan menyisipkan wawasan sosial budaya sehingga problematika pembelajaran IPS Sekolah Dasar dapat diminimalisir.

\section{MODEL-MODEL PEMBELAJARAN IPS SEKOLAH DASAR}

Untuk menumbuhkan motivasi dan partisipasi siswa perlu dikembangkan model-model pembelajaran IPS yang kreatif dan inovatif seperti: Pengajaran langsung (direct instruction), Pembelajaran Kooperatif (cooperative learning), Pengajaran Berdasarkan Masalah (Problem Base Instruction), dan Belajar Melalui Penemuan (inkuiri).

\section{Model Pengajaran Langsung (Direct Instruction)}

Model pengajaran langsung banyak diilhami oleh teori belajar sosial yang sering disebut belajar melalui observasi. John Dolard dan Albert Bandura meyakini bahwa sebagian besar manusia belajar melalui pengamatan secara selektif dan mengingat tingkah laku orang lain. Dasar pemikiran model pengajaran langsung ini adalah bahwa siswa belajar dengan mengamati secara selektif, mengingat dan menirukan tingkah laku gurunya. Atas dasar pemikiran tersebut maka yang perlu dihindari adalah penyampaian pengetahuan yang terlalu kompleks.

Secara umum, pengetahuan dapat dibedakan menjadi dua, yaitu: pengetahuan deklaratif dan pengetahuan prosedural. Pengetahuan deklaratif itu adalah pengetahuan tentang sesuatu. Sedangkan pengetahuan prosedural adalah pengetahuan tentang bagaimana melakukan sesuatu. Dalam menerapkan pengajaran langsung, pengetahuan yang disampaikan kepada siswa perlu disederhanakan, baik pengetahuan deklaratif maupun prosedural.

\section{Model Pembelajaran Kooperatif (Cooperative Learning)}

Menurut John Dewey, kelas seharusnya merupakan cerminan masyarakat yang lebih besar. Maka kegiatan di kelas perlu memberi pengalaman kepada siswa untuk bekerja secara berkelompok. Gordon Alport mengingatkan bahwa kerjasama dan bekerja dalam kelompok akan memberikan hasil yang lebih baik. Setting kelas dalam pembelajaran kooperatif, perlu memenuhi 3 kondisi, yaitu: (a) adanya kontak langsung, (b) sama-sama berperan serta dalam kerja kelompok, (c) adanya persetujuan antar anggota kelompok tentang setting kelas tersebut.

Model pembelajaran kooperatif ini cukup penting karena siswa dapat belajar dengan cara bekerja sama dengan temannya. Anggota kelompok yang lebih mampu dapat menolong temannya yang kurang mampu. Setiap anggota kelompok tetap memberi sumbangan pada prestasi kelompok. Dan yang lebih penting semua anggota kelompok 
dapat bersosialisasi dengan anggota kelompok lainnya sehingga hal ini akan melatih keterampilan sosial siswa dalam bermasyarakat.

\section{Model Pengajaran Berdasar Masalah (Problem Base Instruction)}

Model pengajaran berdasarkan masalah ini mempunyai ciri umum yaitu menyajikan kepada siswa masalah autentik dan bermakna yang akan memberi kemudahan kepada siswa untuk melakukan penyelidikan dan inkuiri. Sedangkan ciri khusus dalam model ini yaitu adanya pengajuan pertanyaan dan masalah, berfokus pada keterkaitan antar disiplin ilmu, penyelidikan autentik, menghasilkan produk/karya, dan adanya kerjasama. Masalah autentik adalah masalah yang terdapat dalam kehidupan sehari-hari dan bermanfaat secara langsung jika ditemukan penyelesaiannya. Sedangkan masalah akademik adalah masalah yang muncul akibat pengaruh dari suatu masalah sehingga memunculkan masalah lainnya. Misalnya, bagaimanakah pengaruh kenaikan harga BBM terhadap harga-harga bahanbahan pokok? Model pembelajaran ini lebih sesuai untuk siswa kelas tinggi atau siswa yang latar belakang pengetahuannya sudah memadai.

\section{Model Belajar Melalui Penemuan (Inkuiri)}

Pembelajaran penemuan merupakan suatu model pengajaran yang menekankan pentingnya membantu siswa memahami struktur atau ide kunci dari suatu disiplin ilmu, siswa aktif terlibat dalam proses pembelajaran, dan memberi keyakinan bahwa pembelajaran akan terjadi melalui penemuan pribadi. Bruner yang memelopori model pembelajaran penemuan ini meyakini bahwa model penemuan ini akan merangsang siswa untuk melakukan penyelidikan sehingga menemukan sesuatu. Misalnya, guru menyajikan topik kepada siswa tentang peristiwa-peristiwa yang memancing pro-kontra atau konflik kognitif, sehingga motivasi dan rasa ingin tahu siswa terpancing. Model pembelajaran penemuan lebih cocok untuk menanamkan konsep-konsep yang dapat ditemukan melalui percobaan dan penyelidikan.

\section{PENDEKATAN DALAM PEMBELAJARAN IPS SEKOLAH DASAR}

Pendekatan pembelajaran merupakan landasan sikap dan persepsi guru tentang bagaimana kegiatan pembelajaran akan dilaksanakan. Landasan sikap dan persepsi guru ini akan menjadi dasar bagi tindakan guru dalam melaksanakan aktivitas proses pembelajaran. Pendekatan-pendekatan pembelajaran IPS yang bisa menjadi landasan sikap dan persepsi tersebut, sebagai berikut: a) Pendekatan lingkungan; b) Pendekatan konsep; c) Pendekatan inkuiri; d) Pendekatan keterampilan proses; e) Pendekatan pemecahan masalah; f) Pendekatan induktif-deduktif; g) Pendekatan nilai; h) Pendekatan komunikatif; i) Pendekatan kesejarahan; j) Pendekatan tematik; k) Pendekatan sosial-budaya.

Dalam pendekatan lingkungan, IPS sebagai mata pelajaran yang membelajarkan siswa untuk bermasyarakat, perlu memperhatikan lingkungan sebagai topik kajian, baik 
lingkungan sosial budaya maupun lingkungan fisik. Pendekatan ini bisa diawali dari lingkungan siswa yang paling dekat yaitu keluarga, untuk menanamkan nilai moral dan aktivitas bermasyarakat. Guru perlu mencermati lingkungan sebagai aspek yang berperan dalam membentuk perilaku siswa, seperti: lingkungan kauman, lingkungan perdagangan, lingkungan pertanian dan sebagainya.

Pendekatan konsep menekankan bahwa pemahaman konsep sangat mempengaruhi perilaku siswa. Konsep tentang keadilan, kesejahteraan, demokrasi, kerja sama, tanggung jawab, dan sebagainya merupakan konsep-konsep yang harus dipahami siswa, bukan sekedar diketahui atau dihafalkan. Pemahaman ini akan membimbing siswa untuk bisa menghayati yang pada akhirnya mampu mengamalkan dalam perilaku sehari-hari.

Pendekatan inkuiri, diawali dengan suatu pertanyaan atau permasalahan yang mengajak siswa untuk ikut berfikir dalam memecahkan permasalahan. Dalam proses inkuiri, akan tumbuh dan berkembang secara spontan rasa ingin tahu dan berpartisipasi dalam pemecahan masalah melalui tanya jawab yang didesain oleh guru. Dalam kegiatan berinkuiri bisa menghasilkan suatu gagasan, ide, solusi, atau menemukan sesuatu yang dicarinya.

Pendekatan keterampilan proses, bertujuan menumbuhkan keterampilan yang berkaitan dengan suatu proses tertentu yang perlu dilatihkan. Menanamkan perilaku tertentu biasanya perlu dilatih dan dibiasakan sehingga nanti akan muncul perilaku yang diharapkan dalam bermasyarakat. Keterampilan proses bisa dimulai dari mencari informasi sampai nanti bisa menginformasikannya. Sumber-sumber menumbuhkan keterampilan proses dalam pembelajaran IPS antara lain peta, globe, gambar atau foto, grafik, diagram, dan sebagainya.

Pendekatan pemecahan masalah, akan mengenalkan siswa pada masalah-masalah dalam kehidupan di masyarakat. Misalnya, masalah lingkungan hidup yang tidak bersih, tata tertib di sekolah yang belum dipatuhi, masalah narkoba, kenakalan remaja, kemiskinan dan sebagainya, bisa dikenalkan pada siswa dan untuk mengungkap bagaimana respon siswa terhadap permasalahan yang ada dalam masyarakat.

Pendekatan induktif, diawali dari mengemukakan kenyataan-kenyataan yang ada di dalam masyarakat berikut fakta dan datanya. Guru dapat mengangkat contoh-contoh konkret, dan kenyataan yang ada di masyarakat, kemudian ditarik generalisasinya dari fakta dan data tersebut menjadi sebuah konsep. Misalnya tentang kemiskinan, korupsi, lapangan pekerjaan, kesejahteraan, dan sebagainya. Pendekatan deduktif, diawali dari konsep-konsep yang telah dipahami oleh siswa kemudian dicarikan contoh-contoh fakta dan data pendukungnya di masyarakat. Pendekatan induktif dan deduktif menjadi saling menunjang untuk menanamkan konsep pada siswa. Untuk siswa sekolah dasar, pembelajaran bisa dimulai dari yang kongkrit menuju abstrak, dari yang sederhana menuju kompleks, dari yang mudah menuju sulit dan dari yang dekat menuju ke yang jauh. 
Pendekatan nilai, dikembangkan untuk menumbuhkan sikap dan toleransi siswa dalam berperilaku di masyarakat, menumbuhkan kepekaan dan rasa tanggung jawab sosial dengan didasari oleh pengetahuan dan keterampilan sosial. Sikap demokratis dan semangat bekerjasama maupun berkompetisi perlu ditumbuhkan sejak dini.

Pendekatan komunikatif, mengutamakan efektivitas komunikasi guru dan siswa. Pendekatan ini memperhatikan tingkat kematangan kognitif siswa dan sekuensial materi atau istilah bahasa yang digunakan guru adalah bahasa yang dapat dimengerti dan dipahami oleh siswa. Bahasa dan istilah-istilah yang digunakan guru haruslah dimengerti dan dipahami sehingga tidak terjadi miskonsepsi atau salah pengertian.

Pendekatan kesejarahan, mengungkap peristiwa masa lalu yang bisa dijadikan contoh (baik maupun tidak baik) bagi siswa, sehingga siswa bisa mengambil makna dan hikmahnya dari peristiwa masa lalu tersebut. Belajar dari nilai-nilai sejarah perjuangan bangsa Indonesia dalam mencapai kemerdekaan maupun peristiwa-peristiwa lain di masa lalu perlu dikembangkan untuk menjadi contoh pengalaman dan pedoman bagi masa mendatang.

Pendekatan tematik, dikembangkan untuk memberikan wawasan siswa yang komprehensif terhadap tema yang ditampilkan. Misalnya tema lingkungan hidup, hasil pembangunan, demokratisasi dan sebagai bisa dikembangkan pada pemahaman siswa yang lebih komprehensif.

Pendekatan sosial-budaya pada dasarnya dimaksudkan untuk menstimulasi peserta didik untuk terlibat dan memahami masalah sedini mungkin. Berdasarkan rangkaian kegiatan pembelajaran pada tahap inisiasi, dapat disimpulkan bahwa: (1) peserta didik lebih mudah dalam memahami isu atau masalah sosial-budaya aktual yang berkaitan dengan materi yang akan diajarkan, (2) peserta didik termotivasi untuk mengungkapkan pemahaman mereka terhadap materi yang akan diajarkan, sehingga tumbuhnya situasi baru bagi peserta didik untuk memperoleh informasi atau pemahaman yang baru dan lebih komprehensif, (3) kemudahan peserta didik dalam memahami isu atau masalah sosialbudaya aktual di masyarakat yang berkaitan dengan materi distimulasi oleh upaya guru memberikan contoh-contoh isu atau masalah yang dekat dengan lingkungan peserta didik, (4) peserta didik tampak antusias dalam menjawab dan mengajukan pertanyaan yang berkaitan dengan isu atau masalah sosial-budaya yang diketengahkan oleh guru. Hal ini berkaitan dengan apa yang dikedepankan oleh Pedersob (1996) dan Solomon (1996), bahwa dimensi proses dalam pembelajaran dengan model berpendekatan sosial-budaya telah tampak sejak awal pembelajaran, karena iklim pembelajaran dalam model ini sangat positif dalam memfasilitasi unjuk kerja peserta didik secara optimal, dan (5) terjadinya peningkatan kinerja guru, yakni guru lebih banyak berposisi sebagai fasilitator dan mediator pembelajaran. Melalui pengkajian terhadap masalah-masalah sosial-budaya yang membutuhkan pendekatan interdisipliner, peserta didik secara almiah dan terstruktur dapat 
meningkatkan literasi sosial-budayanya sekaligus melakukan refleksi terhadap nilai dirinya berkaitan dengan masalah yang dibahas (Waterworth, 2000:201).

Pendekatan-pendekatan tersebut bisa dipilih dan diterapkan guru dengan pengemasan rencana pembelajaran yang aktif, inovatif, kreatif, efektif dan menyenangkan (PAIKEM). Hal ini sesuai dengan UU Sistem Pendidikan Nasional No. 20 Tahun 2003 yang mengisyaratkan bahwa pembelajaran harus dilaksanakan secara interaktif, inspiratif, menyenangkan, menantang, memotivasi peserta didik untuk berpartisipasi aktif, serta memberi ruaang yang cukup bagi prakasa, kreatifitas dan kemandirian, sesuai dengan bakat, minat dan perkembangan fisik serta psikologis peserta didik.

Paradigma pembelajaran konvensioanl yang selama ini dilaksanakan perlu diubah dengan model pembelajaran yang inovatif. Pembelajaran inovatif ini perlu diterapkan, karena: a) Jumlah informasi dan salurannya semakin banyak; b) Tidak semua potensi siswa bisa dikembangkan dengan satu cara saja; c) Orientasi target materi pembelajaran hanya untuk jangka pendek; d) Proses pembelajaran seharusnya berangkat dari masalah nyata dalam kehidupan sehari-hari.

\section{E. METODE PEMBELAJARAN IPS SEKOLAH DASAR}

Metode merupakan salah satu komponen pembelajaran yang cukup berperanan selain komponen-komponen yang lain. Kegiatan pembelajaran yang berkualitas tentu akan mempertimbangkan penerapan metode sesuai dengan karakteristik topik kajian dan materi pelajaran yang akan disampaikan. Metode adalah cara atau teknik yang dianggap efisien dalam menyampaikan bahan atau materi pembelajaran kepada siswa. Oleh karena itu, hendaknya guru mampu memilih dan menentukan metode pembelajaran yang paling efektif dan efisien dalam pencapaian tujuan pembelajaran. Perlu disadari bahwa tidak ada satupun metode yang sempurna dan efektif serta efisien untuk semua topik kajian. Masing-masing metode memiliki keunggulan dan kelemahan masing-masing, oleh karena itu dalam setiap proses pembelajaran IPS diperlukan penerapan metode yang bervariasi.

Macam-macam metode pembelajaran dalam IPS menurut Azis Wahab (1997: 186) antara lain sebagai berikut: a) Metode ceramah; b) Metode tanya jawab; c) Metode diskusi; d) Metode simulasi; e) Metode penugasan; f) Metode permainan (game); g) Metode cerita; h) Metode karya wisata atau studi lapangan; i) Metode sosio drama; j) Metode bermain peran (role playing); k) Metode pameran (eksposisi); 1) Metode proyek. Pemilihan dan penerapan metode pembelajaran perlu mempertimbangkan kriteria-kriteria sebagai berikut: a) Sesuai dengan karakteristik topik kajian yang akan disampaikan; b) Ditunjang oleh sarana dan prasarana yang ada; c) Sesuai dengan latar belakang dan kebutuhan siswa.

\section{F. MEDIA DALAM PEMBELAJARAN IPS SEKOLAH DASAR}

Setiap media pembelajaran memiliki karakteristik dan keunggulan masing-masing maka diharapkan guru dapat memilih dan menentukan macam-macam media sesuai dengan topik 
bahasan dan karakteristik materi pelajaran. Agar pemilihan dan penentuan media tersebut bisa efektif, maka perlu mempertimbangkan beberapa kriteria, antara lain: a) Objektivitas. Dalam memilih media perlu meminta saran atau pendapat dari teman sejawat, bukan berdasar kesenangan pribadi guru; b) Program pembelajaran. Penentuan media bisa menunjang pencapaian tujuan program pembelajaran atau sesuai dengan pokok bahasan yang akan disampaikan; c) Sasaran program. Sasaran program ini adalah siswa yang mengikuti proses pembelajaran, pada usia tertentu mereka memiliki kemampuan intelektual tertentu pula; d) Situasi dan kondisi. Situasi dan kondisi ini berkaitan dengan sarana dan prasarana sekolah atau kelas (ukuran ruangan, bangku, ventilasi, dan lain-lain) dan situasi kondisi siswa (jumlah siswa, motivasi, dan lain-lain); e) Kualitas teknik. Kualitas teknik ini berkaitan kualitas gambar, rekaman audio maupun visual suara, atau alat bantu lainnya; f) Efektivitas dan efisiensi penggunaan. Keefektifan menyangkut penyerapan informasi yang optimal oleh siswa, sedangkan efisiensi berkaitan dengan pengeluaran tenaga, waktu dan biaya seberapa mampu mencapai tujuan yang optimal.

Menurut Suhanaji dan Waspodo, (2003: 170), media pembelajaran memiliki ragam dan bentuk yang bermacam-macam, namun berdasarkan perkembangannya, media dapat digolongkan menjadi: a) Media yang bersifat umum dan tradisional. Contohnya: papan tulis, buku teks, majalah, buku rujukan, dan lain-lain; b) Media yang bersifat canggih. Contohnya: radio, TV, VCD, tape recorder, OHP, LCD, dan lain-lain; c) Media yang bersifat inovatif. Contohnya: komputer, internet, permesinan yang memungkinkan belajar mandiri.

Sedangkan jenis-jenis media pembelajaran IPS Sekolah Dasar dapat dikelompokkan sebagai berikut: a) Alat pengajaran. Contohnya: papan tulis, papan pamer, mesin pengganda; b) Media cetak. Contohnya: buku, majalah, surat kabar, jurnal, bulletin, pamflet dan lain-lain; c) Media visual. Contohnya: transfaransi, slide, film strip, grafik, chart, model dan realita, gambar, foto, peta, globe, dan lain-lain; d) Media audio. Contohnya: tape recorder, pita suara, piringan hitam dan lain-lain; e) Media audio-visual. Contohnya: televisi, VCD, film suara; f) Masyarakat sebagai sumber belajar. Contohnya: narasumber, tokoh masyarakat, dinamika kehidupan dalam masyarakat.

Dengan mengimplementasikan komponen-komponen pembelajaran IPS dengan inovatif, maka pola pembelajaran yang dikembangkan dapat memenuhi kebutuhan belajar peserta didik, tampaknya keseluruhan aktivitas pembelajaran diarahkan pada kepuasan belajar peserta didik, dengan fasilitasi guru sebagai pelaksana pembelajaran. Berdasarkan realitas ini, tampak bahwa model belajar berpendekatan sosial-budaya bukan saja memaksimalkan peran serta atau keterlibatan peserta didik selama pembelajaran, tetapi secara signifikan telah meningkatkan kinerja guru dalam keseluruhan aspek kemampuan dan keterampilan melakukan pembelajaran. Dalam konteks ini, penggunaan modul, gambar, kliping dan bagan konsep yang dikembangkan oleh guru selama berlangsungnya pembelajaran sangat membantu peserta didik dalam memahami konsep-konsep utama 
materi, dan isu atau masalah sosial-budaya aktual yang ada di lingkungan masyarakatnya. Melalui kegiatan pemecahan masalah sosial-budaya secara langsung dalam kegiatan pembelajaran dengan menggunakan konsep-generalisasi yang telah dipelajarinya, akan mengeliminir sikap negatif peserta didik terhadap pembelajaran yang dilakukan oleh guru (McComas, 1993:63).

Dengan demikian, pengembangan pembelajaran IPS SD berwawasan sosial-budaya berbasis PAIKEM dapat meningkatkan motivasi dan budaya belajar peserta didik terhadap IPS sebagai salah satu mata pelajaran yang selama ini dipandang kurang bermanfaat dan membosankan, baik oleh peserta didik maupun masyarakat luas.

\section{G. SIMPULAN}

Pengembangan pembelajaran Ilmu Pengetahuan Sosial sekolah dasar berwawasan sosialbudaya dan berbasis PAIKEM sebagai sebuah langkah inovatif dalam pembelajaran IPS pada jenjang sekolah dasar dapat meminimalisir kekurangan-kekurangan dalam membelajarkan peserta didik dalam memahami IPS di sekolah dasar sekaligus untuk meningkatkan kualitas proses pembelajaran IPS sekolah dasar, guru perlu aktif, kreatif, dan selektif dalam menerapkan model-model pembelajaran serta pendekatannya.

Dalam memilih dan memanfaatkan media belajar perlu disesuaikan dengan karakteristik bahan belajar yang akan disampaikan. Penyampaian materi belajar dengan menerapkan metode belajar yang bervariasi akan mendorong motivasi siswa dalam mengikuti proses pembelajaran sehingga tujuan bisa tercapai lebih efektif dan efisien. Pemanfataan media pembelajaran perlu dipertimbangkan secara objektif dengan mendasarkan pada sarana dan prasarana yang ada.

Berdasarkan permasalahan pokok dan hasil serta pembahasan sebagaimana yang telah diuraikan di atas, maka dapat diformulasikan beberapa simpulan sebagai berikut: (1) prosedur pembelajaran dengan model belajar berpendekatan sosial-budaya memberikan keleluasaan yang optimal bagi peserta didik untuk berimprovisasi selama berlangsungnya pembelajaran sehingga dapat menciptakan iklim dan aktivitas belajar yang kondusif; (2) dilihat dari efektivitas model belajar berpendekatan sosial-budaya terhadap peningkatan pemahaman materi IPS oleh peserta didik, tampak bahwa pemahaman peserta didik terhadap materi yang diajarkan memperlihatkan grafik yang meningkat, dan pada tahap uji coba model, hasil tes evaluasi yang dilakukan menunjukkan bahwa rerata skor evaluasi belajar peserta didik yang dibelajarkan dengan model belajar berpendekatan sosial-budaya lebih tinggi daripada skor rerata peserta didik yang dibelajarkan dengan model belajar konvensional; dan (3) terjadi peningkatan literasi sosial-budaya peserta didik yang 
berkaitan dengan materi yang dibelajarkan dalam pembelajaran IPS berpendekatan sosialbudaya dan berbasis PAIKEM. 


\section{DAFTAR PUSTAKA}

Ausubel, D.P.1968. The Psychology of Meaningful Verbal Learning. New York: Grune and Straton.

Degeng, I.N.S. 1989. Ilmu Pengajaran: Taksonomi Variabel. Jakarta: P2LPTK.

Gagne, R.M. 1974. Essentials of Learning for Instruction. New York: Holt Rinehart and Winston.

Gagne, R.M. dan Briggs, L.J. 1979. Principles of Instructional Design. New York: Holt Rinehart and Winston.

Jarolimek, J. 1993. Social Studies in Elementary Education. New York: Mac Millan Publishing Co Ltd.

Kurikulum Tingkat Satuan Pendidikan. 2006. Mata Pelajaran Ilmu Pengetahuan Sosial Jakarta: Depdiknas.

Muslimin Ibrahim. 2007. Pembelajaran Aktif, Inovatif, Efektif, Kreatif dan Menyenangkan. Surabaya: FIP Unesa.

Nu'man Somantri. 2001. Menggagas Pembaharuan Pendidikan IPS. Bandung: Remaja Rosda Karya.

Reigeluth, C.M. 1983. Instructional-Design Theories and Models: An Overview of Their Current Status. London: Lawrence Erlbaum Associates, Publishers.

Salomon G. 1972. "Heuristic models for the generation of aptitude-treatment interaction hypotheses". Review of Educational Research. No. 42: 327-343.

Schuncke. GM. 1988. Elementary Social Studies. Knowing, Doing, Caring. New York: Macmillan Publishing

Slamawi,1996. Konsep Dasar Ilmu Pengetahuan Sosial. Jakarta: Ditjen Dikti

Snelbecker, G.E. 1983. Is Instructional Theory Alive and Well? New Jersey: Lawrence Erlbaum Association.

Suhanaji dan Waspodo Tjipto Subroto. 2003. Pendidikan Ilmu Pengetahuan Sosial. Surabaya: Insan Cendikia.

TIM UNESA. 2007. Model-Model Pembelajaran Inovatif. Surabaya: University Press Unesa.

Waspodo Tjipto Subroto dan Suhananji. 2005. Pengetahuan Dasar Ilmu-Ilmu Sosial (Geografi, Sejarah, Ekonomi, Politik, Sosiologi, dan Antropologi). Surabaya: Insan Cendikia 